\title{
Confucianism vs. Modernity: Expired, Incompatible or Remedial?
}

\author{
Geir SIGURĐSSON*
}

\begin{abstract}
This paper is an exploration of the reappraisal that has been taking place since the 1980 s of Confucianism's suitability for a modernized society. The first section focuses in particular on the discussion that took place in Singapore on Confucianism as a stimulant for economic activity, arguing that it was first and foremost a politically motivated attempt to establish Confucianism as a convenient ideology. I then move to a discussion of recent attempts to rehabilitate Confucianism in the PRC. In the final section, I suggest how Confucianism can be a healthy antidote to some of the ills produced by contemporary capitalist practice.
\end{abstract}

Keywords: Confucianism, modernization, capitalism, consumerism

\section{Izvleček}

Ta članek raziskuje prevrednotenje primernosti konfucionizma za modernizacijo družbe, ki se odvija od 1980. Prvi del se osredotoča predvsem na razpravo, ki je potekala v Singapurju o konfucianizmu kot poživilu za gospodarske dejavnosti, z utemeljitvijo, da je bil najprej in predvsem politično motiviran poskus vzpostavitve konfucionizma kot priročne ideologije. Nato preidem na razpravo o nedavnih poskusih vnovične rehabilitacije konfucionizma v Ljudski republiki Kitajski. V zadnjem poglavju pa predlagam, kako je lahko konfucionizem zdrav protistrup za nekatere tegobe, ki jih proizvajajo sodobne kapitalistične prakse.

Ključne besede: konfucianizem, modernizacija, kapitalizem, potrošništvo

\footnotetext{
* Geir SIGURĐSSON, Senior Lecturer (Associate Professor), Chinese Studies, Vice-head, Department of Foreign Languages, Literature and Linguistics, University of Iceland geirs@hi.is
} 


\section{Introduction: The Changing Meanings of Confucianism}

The term "Confucianism", whether in its Western version or its Chinese equivalent rujia 儒家, is gradually receiving a new, while still inchoate, signification. Its meaning will probably never be entirely clear, nor, I argue, has it ever been. As with any complex philosophy or ideology with a long history, it is notand most likely should not be-easily definable. While a number of specific Confucian values, approaches and notions can be identified, Confucianism's lack of indispensable foundations or dogmas eschews rigorous definitions. What is at least clear, however, is that its point of reference in academic and even public discussion has recently been undergoing considerable changes. Today, "Confucianism" is beginning to literally mean something rather different from what it did only three decades ago when it was predominantly understood as the major stream of thought in ancient China, and, somewhat more narrowly, as the ruling ideology of the Chinese dynasties. Back then, however, and during most of the $20^{\text {th }}$ century, Confucianism was only rarely presented as a viable or desirable way of thinking. On the contrary, in fact, it was largely rejected, and sometimes even persecuted, as a relic of the past and the primary culprit of China's alleged stagnation during the last few centuries of dynastic rule (Chen 2011, 205).

The fact, however, that not everyone rejected Confucianism in this manner should not be understated. A number of philosophers in Taiwan and Hong Kong, for instance, significantly upheld the reverence for the Confucian enterprise during the $20^{\text {th }}$ century. Thinkers who held comparable views were certainly also present in the People's Republic of China, while state repression provided little if any possibilities for them to expound their views without running the risk of suffering serious personal consequences. Some prominent Western sinologists, moreover, engaged themselves critically but in many cases also constructively with Confucianism as a philosophical tradition worthy of consideration.

But the link with modernization was rarely, if at all, made until in the 1980s. Indeed, until very recently, few Western sinologists or other academics would even dare mention Confucianism and modernity in the same sentence. It would simply not occur to the majority of them that Confucianism might have anything to offer to a "modern" or "modernizing" society. While certainly of indisputable historic importance, Confucianism tended to be regarded as comparable perhaps to 
medieval Christianity, a previously powerful ideology that had all but outlived its days. $^{1}$

The decisive first steps taken towards a reevaluation of Confucianism were taken in the 1980s. While dialogues took place in China and Taiwan about Confucianism's suitability for a modernized society, it was in Singapore that Confucianism was first suggested as a potential catalyst for modernization after Lee Kuan Yew's government introduced Confucian ethics in the secondary curriculum in 1982. What ensued was a major philosophical, sociological and economic discussion hosted by the Institute of East Asian Philosophies (IEAP), which was established at the National University of Singapore in 1983, about Asian and notably Confucian values as an appropriate platform for social and economic modernization. The aim seemed to be taken towards a Confucian revival, or perhaps rather inception, as it is questionable whether Confucianism had ever been a strong cultural force in the city state. The government-sponsored Confucian programme in Singapore sought to find values and motivations inherent in Confucianism that could establish it as being parallel to the Protestant ethic in its Weber-inspired image, i.e. as a cultural force informing ways of living that forge ahead capitalism, industrialization and modernization. Apparently, hopes were high that an Asian cultural stimulant for a social and economic progress comparable to earlier breakthroughs in Euro-America would be discovered and affirmed. Confucianism was perceived as an important strand in and aspect of what came to be called "Asian values", a broader cultural base on which modernization could be constructed while westernization could be avoided.

But not everyone was in such a hurry to come to the desired conclusion. Tu Weiming, the well-known scholar of Confucianism, then based at Harvard University, was brought into the dialogue as a leading authority in the field. As Tu is generally considered a champion of Confucianism, one would have expected him to be eager to identify and affirm its positive and modernizing effects. But Tu is also a careful and thorough scholar. One may surmise that he failed to fulfil the high expectations of his hosts as he was unwilling, as published in a later paper, to

\footnotetext{
${ }^{1}$ Besides the many May Fourth and Maoist denouncements of Confucianism in $20^{\text {th }}$ century China, a prominent view of Confucianism as a relic of the past is found in Joseph R. Levenson's monumental Confucian China and its Modern Fate, in which he concludes that "Confucian civilization" is merely historically significant in much the same way as ancient Greek and Egypt civilizations (Levenson 1958-1965, 3: 123f.).
} 
subscribe to the thesis that Confucianism "provides a necessary background and powerful motivating force for the rise of industrial East Asia", arguing that

the method of finding the functional equivalent of the Protestant ethic in the "modernized" or "vulgarized" Confucian ethic is too facile, simple-minded, and mechanistic to merit serious attention. (Tu 1993, 8)

He further wrote:

The question, In what sense has the Confucian ethic contributed to the economic dynamics of industrial East Asia? seems less interesting than a much more profound subject of investigation: How does the Confucian tradition, in belief, attitude, and practice, continue to impede, facilitate, and guide the modern transformation in East Asia and, in the process, how is it being rejected, revitalized, and fundamentally restructured? (Tu 1993, 13)

It appears that Singapore's endorsement of Confucianism as a modernizing power was largely intended as a self-fulfilling prophecy. An ideology convenient for an authoritarian regime was to be established on the grounds that it was the cultural basis of Singapore's economic success story. Thus, the discussion was first and foremost ideologically driven rather than searching for real understanding, while a number of good scholars participating in the dialogue certainly aimed at and contributed to the latter. By concocting a Confucian cultural foundation, the People's Action Party under Lee Kuan Yew's leadership had found a vindication for continuing its authoritarian rulership in a period of world history characterized by growing demands for stronger democratic principles. The state was attempting to "naturalise, validate, and ironically reunite (Chinese) Singaporeans with a presumed moral and philosophical code." (Yew 2011, 277) Ong Pang Boon 王邦 文, a first generation People's Action Party politician, and an outspoken critic of the Confucian programme, warned that

successive generations of monarchs had always made use of and promoted those parts of Confucianism that were advantageous to feudal rule. (Hong and Huang 2008, 105)

In this respect, it is illuminating that in the 1970s and into the mid-1980s, the Singapore leadership praised and encouraged "rugged individualism" until it suddenly began endorsing a Confucian kind of collectivism, duty and self-sacrifice. (Englehart 2000, 555) 
The Confucian programme in Singapore turned out largely to be a failure, most decisively due to fear by other ethnic groups that the country was being Sinicized, but also because of scarce interest and even opposition by the Chinese population (Yew 2011, 277). The Institute of East Asian Philosophies was changed in 1990 to the Institute of East Asian Political Economy (IEAPE) and given different tasks in line with its new name. ${ }^{2}$

Around the same time in the People's Republic of China, or in the wake of the Four Modernizations campaign launched at the end of the 1970s, a radical reexamination of Confucianism began taking place. This was a time calling for a thorough reconsideration of the present and future status of the various ideological, philosophical and religious forces in the PRC. Much of the discussion during the first years revolved around Confucianism's adaptability to the official Marxist state-ideology. This particular issue was of broader political nature and applied to major religions such as Buddhism and Christianity as well. But Confucianism's historical and cultural status is only partly comparable to that of other religions and therefore required a more differentiated treatment. Not only is Confucianism not represented by some kind of ideological establishment, such as a church, but it was and still is considered by many as some kind of locus or core of Chinese culture that transcends any ideological categories, or, as Li Zehou 李泽厚 has put it, a "psycho-cultural construct" beyond the manipulation of human will. (Song 2003, 88) Thus, an acceptance of Confucian deep-seated social and cultural influences would call for an investigation into its compatibility with a modernizing society.

While the discussions in China and Singapore were set against different backdrops, the former was somewhat influenced by the latter. For instance, some of the participants, such as Tu Weiming, were active both in China and in Singapore. The cultural implications of Singapore's notion of "Confucian capitalism” (rujia zibenzhuyi 儒家资本主义) may to some extent be meaningfully compared with China's notion of "socialism with Chinese characteristics" (Zhongguo tese shehui zhuyi 中国特色社会主义), although Confucianism’s impetus for economic modernization was only fleetingly addressed in China, perhaps, one may surmise, because China was officially still socialist and not

\footnotetext{
${ }^{2}$ In 1997, the Institute of East Asian Political Economy was then changed again into the still operating East Asian Institute. On the opposition to and eventual failure of the Confucian programme, see Kuo (1996, 303ff.).
} 
heading towards becoming a capitalist country. Fang Keli, an influential MarxistConfucian thinker, "was adamant that mainland scholars did not advocate the road of 'Confucian capitalism', and that what they were exploring was the socialist road to modernization with Chinese characteristics." (Song 2003, 95) Thus, whether or not in line with the views of those participating in the debate, it seems that such considerations were more or less brushed aside and the main attention turned toward Confucianism as a cultural, ethical and even "religious" foundation in China. The 1980s debate was, after all, termed "culture craze" or "culture fever" (wenhua re 文化热), indicating that it revolved mostly around the search for a national culture suitable for China's intention to find its place among other modernized nations of the world.

\section{Confucianism's Present Status in the People's Republic of China}

The "culture craze" came to a halt with the repressive political situation in China after the student revolts were crushed in 1989. But the question of Confucianism's place in China's future was by no means forgotten. Already in the mid-1990s it was becoming obvious that a reconsideration of Confucian values was inescapable. This has become even more obvious in the new millennium, when Confucianism has been enjoying positive reappraisal in China as a kernel of a new and still ongoing "craze" of "national learning” (guoxue 国学). A grassroots embrace of Confucianism is taking place, and a clear, while also clearly debated, top-down endorsement of Confucian culture has been occurring, manifesting itself in both private and public schools that teach Confucian values and virtues, university institutes for the furtherance of Confucian studies, ${ }^{3}$ not to mention the now more than 300 Confucius Institutes operating all over the world. While the Confucius Institutes are not, as many people seem to believe, specifically designed to further the Confucian philosophy as such, they are certainly symbolic for the radically changed attitude to Confucius and Confucianism in the PRC.

A growing number of intellectuals in China are now considering Confucianism in a favourable manner. Some of these even explicitly endorse it as a viable

\footnotetext{
${ }^{3}$ The first institute of such a kind, the Chinese Confucius Research Institute (中华孔子研究所), was established already in 1985 in the birthplace of Confucius, Qufu. In the new century, however, they have proliferated and been established at various universities in China, for instance, at Renmin University of China in Beijing in 2003 (孔子研究院), Qufu Normal University in 2007 (孔子文化学 院), Sichuan University in 2009 (国际儒学研究院), Shandong University in 2010 (儒学高等研究院) and Peking University in 2010 (儒学研究院).
} 
ideology for China's future. Others suggest it more as a practical guide for everyday life. Among those belonging to the first group, Jiang Qing 蒋庆 and Kang Xiaoguang 康晓光 are probably the best known thinkers. They differ, however, considerably in their approaches and motivations. Jiang, a selfproclaimed Confucian, believes in the correctness of Confucian institutions, way of life and values. ${ }^{4}$ Kang, on the other hand, is rather a pragmatic thinker who, while not considering himself a Confucian, believes that the foundation of a unifying institute such as a "Confucian church" would have beneficial effects on the anomical state of Chinese society. ${ }^{5}$ In the second case, I am of course primarily referring to $\mathrm{Yu}$ Dan's 于丹 somewhat controversial but overall popular interpretation of the Analects. ${ }^{6}$

Within the continuous educational reforms in China, Confucian values and insights have received and are receiving more and more attention as potential sources for moral education and existential meaning, not least during the previous leadership of Hu Jintao and Wen Jiabao, who "moved closer to an official embrace of Confucianism" and repeatedly came up with Confucian-based slogans and encouragements such as "harmonious society", "filial piety" and "eight glories and eight shames". (Bell 2010, 91f) It is still too early to detect the attitude of the present leadership to Confucianism, but on the surface it seems certainly less openly supportive of a Confucian-inspired policy. One may surmise that the bizarre case of Confucius's statue on Tiananmen Square in 2011, erected in January, removed overnight in April, may be associated with a more skeptical attitude to Confucianism with the then incumbents-to-be. (Gardner 2011)

Be that as it may, the growing number of positive allusions to Confucian ways of thinking, both in media and on the political arena in China, makes it increasingly urgent to come to a better understanding of their meaning. While it would be easy to dismiss these allusions as empty and meaningless, as much of Western media often does, I believe that such cynicism is unhelpful, and that we should rather be taking them reasonably seriously. ${ }^{7}$

\footnotetext{
${ }^{4}$ Jiang's ideas of Confucianism's future political role in China are well presented in Fan (2011).

${ }^{5}$ The best English introduction to Kang's suggestions and approaches is found in Gaenssbauer (2011).

${ }^{6}$ On its controversial nature, cf. Zhao (2007).

${ }^{7} \mathrm{Cf}$. Shobert (2011) who implies that in Chinese politics "Confucianism is a tool to be employed, a means to an end" of silencing any opposition in the country, and Roberts (2012) similarly concludes his article by citing a Hong Kong-based scholar who says that the "Party uses Confucianism as a tool,
} 
Hence an important question is what Confucianism means, or should mean, in a contemporary context. This question obviously also begs the question what sort of form it might take in its future development in China. The second and probably more important question is what, if anything, Confucianism can offer modernity: whether it is still, or perhaps once again, relevant to modern societies. This is of course a topic for many dissertations and books and here I can only briefly touch upon a few pressing issues.

With regard to the contemporary meaning of Confucianism, there is no simple and fixed definition or formulation that could fill in the blanks for us-not even from a historical point of view. Confucianism has a long and a highly syncretic history, it has, explicitly or not, been generally rather inclusive of other streams of thought in China, and was so pervasive in Chinese society that there were few if any aspects of human living that had no association with it at all. As the Confucian reformer Liang Qichao 梁启超 remarked in his Confucian Philosophy 儒家哲学 from 1927, "Confucian philosophy does not equate with the whole of Chinese culture, but if you take Confucianism away, I am afraid that not much else will remain." ${ }^{\prime 8}$ (cited in Zhou 2011, 27) To conflate Confucianism with Chinese culture would certainly be an over-generalization that left the label largely meaningless. But one can hardly deny that Confucianism has been pervasive in the entire cultural history of China.

Confucianism has been many things and it has had many paradoxical manifestations - some of which were present at the same time. In its ancient form as philosophy, it was anti-dogmatic in nature, flexible and adaptive. During the Han-dynasty, it was a powerful but also a largely creative state ideology. In its Neo-Confucian guise, it was highly syncretic, lofty and idealistic, while also practical and realpolitical. In the Ming and Qing, it became inward-looking, somewhat dogmatic, nostalgic and thus reactionary. It was always a motivation for learning, although the learning it encouraged may not always have been, as it was meant to be, appropriate for the times. Confucianism also always justified hierarchy, both within family and society at large — but the hierarchy it justified

as a way to legitimize their rule, and as a way of criticizing Western democracy". An editorial in Der Spiegel also concludes that Confucianism may be a convenient ideology for the CCP by assuming a misleading interpretation of a passage from the Analects (12.19): "the virtue of the junzi is like the wind, while that of the xiaoren like the grass. As the wind blows, the grass is sure to bend." (Brüder im Geiste 2007)

8 “儒家哲学，不算中国文化全体；但是若把儒家抽去，中国文化，恐怕没有多少东西了。” 
was often realistic and not necessarily rigid. Which of all these Confucianisms do people want? And is the Confucianism people want really still Confucianism? And, perhaps more importantly, who are these people?

In any case, it probably goes without saying that the institutionalized, or indeed, politicized Confucianism of fixed moral codes and hierarchies is unlikely, to say the least, to gain much ground with the Chinese population at large. Considering its heightened exposure to persuasive "global" (i.e. predominantly Anglo-American) values, such as individualism, negative freedom and increased consumer choice, as well as other progressive social changes in China, such as improved women's rights, this development will exclude, or has already excluded, the possibility of anything close to the formerly institutionalised Confucianism to be reconstructed.

Hence, should Confucianism continue to be interpreted in a historicist manner by specialists on Confucianism, who tend to identify it with the reactionary Qing Dynasty establishment, then it would appear unlikely that the population will embrace the Confucian ideology. On the other hand, it is intriguing that Yu Dan's highly popular interpretation of Confucianism has precisely been criticized for being too accommodating to the status quo; critics say "that her thinking and her lecturing resemble a scholar-official from the feudal society", aiming at the reduction of critical social input in order to "maintain harmony", virtually as if the May Fourth Movement had never existed. (Zhao 2007) And yet, however curiously, the public readership seems to embrace it.

Perhaps such criticism of Yu Dan is too subtle, perhaps even pedantic. A guide through everyday life rooted in local culture may simply find easier access to people's way of thinking and valuing than foreign self-help manuals. Even so, a return to a dynastic kind of Confucianism would seem entirely out of place. The New Confucian movement that has sought to find some commensurability between the Confucian philosophy and modern (or Western) institutions and values such as democracy, human rights, gender justice and individualism would seem to be the most promising for a kind of Confucianism suitable to the modern times. On the other hand, it must also be taken into account that Confucianism cannot simply be a vehicle to implement "modern" values in their Western format. If such values are to be adopted, as Daniel Bell has correctly observed, they must also be adapted (Bell 2010, 93). 


\section{Confucianism's Contribution to the Modern World: A Suggestion}

Whether Confucianism is capable of adapting to modernity, however, does not answer the question whether it has something specific to contribute to modernity. In this regard, I would like to propose a suggestion. Which issues are the most pressing ones in modernity? Currently, economic considerations are without doubt the most conspicuous ones. Has Confucianism anything to contribute to these issues? I believe so, but in a way rather different from what people might expect. Let me explain.

As touched upon in the first part of this paper, the last few decades have witnessed much discussion about what sort of influence Confucianism would have (and has had) on capitalist enterprise. Although the Chinese Communist Party was prone to regard Confucians as "capitalist-roaders", Confucianism had, in history, probably somewhat restraining effects on commerce and market forces, as it assigned merchant activity a very low social status, which, admittedly, was rather a reflection mainly of Legalist views. (Hansen 2000, 99) This tendency has been criticized by some historians as having inhibited the development of Chinese society, eventually causing it to lapse behind the Western powers (e.g. Fairbanks and Goldman 2006, 179ff). There is probably some truth in this, but today we may need to reevaluate this entire historical development as it has arguably triggered a number of grave problems in the world at large, social, moral, environmental and even existential. Indeed, considering the long-term interests of humanity and other living beings on the planet, the narrative of the West's success may in fact turn out to be simply a brief preface to the horror story of humanity at large.

There are other and more recent arguments for considering Confucianism in fact a catalyst for capitalist activity. I will not go into detailed discussion of these arguments here, but briefly explain my conviction that most of these are actually misguided, partially resting upon a mistaken interpretation of Max Weber's Protestant Ethics thesis as an explanation of, let alone a blueprint for, desirable progress. Weber was concerned about the process of increased rationalization (Rationalisierung) in the Western way of living, thinking and valuing, certainly triggering a more systematic approach to organized co-existence, but also leading to depersonalization, loneliness and isolation. The fateful factor in this process was the quest for money-making, stimulated unintentionally by certain Protestant theological interpretations, and leading to the unique Western capitalist system, which Weber envisaged as becoming dominant in Western culture with all its 
inhumane and deplorable consequences. ${ }^{9}$ In this process, money-making becomes not only a rationalized activity but one that takes precedence over all other human activities: it becomes an end in itself. According to Weber, the unique feature of Occidental capitalism derives from its reliance upon an inner motivation to strictly organize our mundane life in such a way that virtually all of our actions contribute to the accumulation of capital. But not only is this an absurd and meaningless way of living, it also has profoundly negative consequences for human civilization and the "quality" of the human creatures being moulded by such a framework of values when gaining ascendancy in our societies. ${ }^{10}$ Weber would certainly have agreed that the process of rationalization has brought many improvements to Western societies, but considering his ironic remarks towards the end of his Protestant Ethic and the Spirit of Capitalism, it seems evident that he did not regard the "capitalist revolution" as a civilizational progress, and in fact rather the opposite:

For of the last stage of this cultural development, it might well be truly said: "Specialists without spirit, sensualists without heart; this nullity imagines that it has attained a level of civilization never before achieved." (Weber 1930, 182)

Thus, to base one's quest for cultural factors giving rise to social progress on Weber's thesis seems seriously misguided unless it is utilized as a powerful critique of modernity's ills.

There is in any case a pressing need to reform the global capitalist system and radically reconsider the underlying values that help to maintain it. Marxism or socialism, at least of the conventional kind, is probably not that effective, not only because of its painful repressive history that has made it unattractive, but also because it is based on the fundamental idea that the system needs to be overturned before the way people think can be changed. We should have ample examples from history to realize to what sort of results such efforts tend to lead. Confucianism starts at the other end, with pedagogy, and seeks to instil certain

\footnotetext{
${ }^{9}$ Tu Weiming $(1984,86)$ observes in this respect that "the Protestant ethic that has contributed to the rise of capitalism in the West has led to all kinds of problems such as excessive individualism and excessive rights-consciousness. (...) Excessive self-interest has led to the fragmentation of the individual, the generation gap and other problems of similar gravity."

${ }^{10}$ It is illuminating for Weber's overall project that when hard-pressed by his critics to explain the focal point of his extensive comparative social and cultural investigations of which the Protestant Ethic was a part, he himself said that it was "not the advancement of capitalism in its expansion that was of central interest" to him, "but the evolution of the humankind [Menschentum] shaped through the confluence of religiously and economically dependent factors." (Weber 1978, 303)
} 
values and ways of thinking that contribute to a flourishing human co-existence and may even be necessary for the future of human societies and life on earth as a whole. Should it be unclear whether Confucian traits are likely to have a stimulating effect on industrial producer capitalism, it seems far less compelling when considering our modern consumer capitalist system. For Confucians would in most circumstances be reluctant consumers and generally rather frugal. Interestingly, however, they would not see anything wrong as such with material wealth to the extent that it simply provides conditions for good living. At first glance, this may seem contradictory, but, as will be clear, a closer look at the Confucian teachings reveals that it is not. Ruiping Fan has made the following observation about the Confucian attitude to material wealth:

Material rewards are accepted as generally good, so that there is a pragmatist affirmation and openness to various means (such as central planning, the market, or both) as the source of monetary wealth, which is in turn a source of family and individual well-being. Confucians are this-worldly in pursuing a good life and human flourishing. They work for their families within a nonPuritanical acceptance of material success in this world in which material wealth is taken as, ceteris paribus, good and not grounds for moral suspicion. Wealth is desirable and should be pursued, as long as one does not pursue it by violating morality. (Fan 2010, 233)

Wealth, however, is not an acceptable goal in its own right, as Confucius himself states rather clearly in Analects 7.12:

If wealth were an acceptable goal, even though I would have to serve as a groom holding a whip in the marketplace, I would gladly do it. But if it is not an acceptable goal, I will follow my own devices. (Analects 1998)

On another occasion, where Confucius is engaged in conversation with one of his disciples, he expresses his approval of the dictum "Poor but enjoying the way; rich but loving ritual propriety" (1.15). This view comes through more clearly in the following statement:

Wealth and honor are what people want, but if they are the consequence of deviating from the way, I would have no part in them. Poverty and disgrace are what people deplore, but if they are the consequence of staying on the way, I would not avoid them (4.5).

Wealth is thus first and foremost an expedient tool for improving one's moral development. Other things being equal, it is to be preferred to poverty, but only 
insofar as it will not corrupt the individual in question. After all, Confucius has nothing against making a nice profit:

Zigong said, "We have an exquisite piece of jade here-should we box it up and put away for safekeeping, or should we try to get a good price and sell it off?" The Master replied, "Sell it! By all means, sell it! I am just waiting for the right price!" (9.3)

Greed, egotism and extravagance, however, are all deplored. When fishing, Confucius himself avoided excess by using a line, not a net (7.27). Frugality is presented as a commendable virtue, while miserliness is not. Nevertheless, frugality leading to miserliness is better than extravagance leading to immodesty (7.36). An exemplary person (junzi 君子) is often contrasted with the petty person (xiao ren 小人) whose actions are motivated by narrow egotistic interests of personal gain instead of a sense of fairness or the desire to advance public welfare $(4.11 ; 4.16)$. Exemplary persons, on the other hand, come to the assistance of those in need, but do not increase the wealth of those who are already wealthy (6.4; 11.17).

"I have heard," Confucius says, "that the ruler of the state or the head of a household: Does not worry that his people are poor, But that wealth is inequitably distributed ... For if the wealth is equitably distributed, there is no poverty" (16.1).

The assumption is that there are sufficient resources for everyone to live decently, and that scarcity is caused by individual greed of those in power. When the despot King Xuan of Qi confides in Mencius that he is fond of both money and sex, Mencius (1970, 1B.5) reassures him that such fondness is perfectly acceptable as long as it is shared with the people. Already in antiquity, Confucian thinkers identified the harmful social effects of economic inequality: "The accumulation of wealth" as it says in the "Great Learning" chapter of the ancient Book of Rites (Liji 礼记), "is the way to scatter the people, and the distribution of wealth is the way to collect the people" ( $\mathrm{Li}$ Chi 1967 (Daxue §26)). Wealth is a means to the end of a good life, not an end in itself. "Virtue is the root; wealth is the branches," as the Book of Rites states quite clearly (Li Chi 1967 (Daxue §26)). The point, in other 
words, is not material goods and their acquisition and consumption, but decent human living. ${ }^{11}$

The values nurtured in our capitalist economic system, values that capitalism needs in order to thrive, are, on the contrary, most certainly destructive with regard to social solidarity, the environment and natural resources. I would even go so far as to state that current capitalist practice is comparable with cancer: its demand for continuously increased consumption is undermining virtually all the conditions for life, human or non-human, to flourish on earth. There is no lack of arguments for this, despite the continuous efforts of powerful interest groups to diffuse them. Underlining the serious state of the current environmental situation in the world, a number of European scientists have recently called for new approaches to environmental issues in light of the emerging and formidable impact of human activity on planet earth:

It has created a completely novel situation that poses fundamentally new research questions and requires new ways of thinking and acting. (Palsson 2013, 2)

This emerging epoch, in which human activity must "be considered a 'driver' of global environmental change", has been referred to as the "Anthropocene" (Palsson 2013, 2). ${ }^{12}$ Asking for a healthy integration of both natural and human sciences in environmental studies, these scientists argue that the human being cannot any more be considered apart from nature, and "the environment must be understood as a social category". (Palsson 2013,4) This would seem to require quite novel perspectives on the nature-human relationship and may even challenge us to think about the categories of nature and human in new terms:

Nature has often been presented as one half of a pair-nature/culture, natural/social, and so on. This is still echoed in some earth-system notions that are fundamentally dualistic, "linking", "connecting", and "coupling" the two systems of the earth and humans as if they were different realities. But

\footnotetext{
${ }^{11}$ I provide a more detailed discussion of the Confucian (as well as Daoist and Mohist) views of consumption in Sigurðsson, 2014.

${ }^{12}$ Cf. Ellis and Haff $(2009,473)$ : "We live in the Anthropocene: For better or for worse, the Earth system now functions in ways unpredictable without understanding how human systems function and how they interact with and control Earth system processes. Regardless of whether this transition from the Holocene (generally thought of as the past 12,000 years) to the new epoch of the Anthropocene will ultimately be for the better or for the worse, the Earth system will not be returning to a preanthropogenic state for the foreseeable future."
} 
recently, environmental discourse has increasingly emphasized the need to move beyond the stark dualism of the natural and the social. (Palsson 2013, 7)

Some of the main reasons for such an emphasis are the outcomes of empirical research, suggesting that the human impact on natural occurrences and even genetic conditions of both humans and animals is considerably more than believed up to now. Thus, a strict demarcation of the human vs. the natural is increasingly being seen by scientists as an unrealistic reflection of the real state of affairs.

Importantly, this awareness of the new "human condition", to use Hannah Arendt's well-known term, has profound ethical implications. A classic modernist approach to the environment purely as a resource for human consumption is no longer viable. As the aforementioned scientists point out:

We are only part of a complex network of elements and relations that make up planet earth, but we are the only part that can be held responsible. (Palsson 2013,9)

They go on to refer to Feminist theory and ethics of care as potential alleviators of this rigid modernist approach, which, despite an awareness of the need for change, retains us in an economic model whose aims are directly antagonistic to the environmental situation.

Some of us are desperately seeking resources in our culture to deal with this pressing problem. This is because the only real and lasting solution can be cultural. Patch-up jobs on the current framework of values, way of living and views on the relationship between individual and mankind as a whole will not do. It is well worth investigating whether the Asian cultural and philosophical sensibilities, perhaps Confucian, Neo-Confucian or even Daoist and Buddhist ones, having operated for a long time in a much more "responsive" conceptual relationship with nature, may have something to teach us. Indeed, Confucianism with all its syncretic and open-ended tendencies may have had its best moments when incorporating elements from all these systems of thought. The yin-yang kind of dualism seems for instance much more realistic than our sharp-ended PlatonicChristian-Cartesian dualism, stimulating a "softer" and certainly more moral relationship between man and world, and thus being more likely to contribute to the formation of a culture of sustainability.

To conclude, humanity is in need of a new culture, not simply a new system. We need a culture, a grassroots culture that promotes certain values, according to 
which uninhibited profit-making is simply considered an unaesthetic, a deplorable or a shameful activity. In this sense, something quite radical is needed, and I believe that there is much in the Confucian teachings, its outlook on human coexistence, the symbiosis between human and nature and an elegant kind of human living, from which contemporary human beings - Chinese or non-Chinese — can learn.

Confucianism is certainly not expired; it may be incompatible with modernity as it is, but that is because there is precisely something very wrong with modernity as it is, something that is in desperate need of being remedied.

\section{References}

The Analects of Confucius. A Philosophical Translation. 1998. Translated by R.T. Ames and H. Rosemont, Jr. New York: Ballantine Books.

Bell, Daniel A. 2010. "Reconciling Confucianism and Socialism? Reviving Tradition in China." Dissent Magazine (Winter).

“Brüder im Geiste." 2007. Der Spiegel 3. http://www.spiegel.de/spiegel/print/d50186303.html

Chen, Albert H.Y. 2011. "Three Political Confucianisms and Half a Century." In The Renaissance of Confucianism in Contemporary China, edited by Fan Ruiping, 205-23. Dordrecht: Springer.

Ellis, Erle C., and Peter K. Haff. 2009. "Earth Science in the Anthropocene: New Epoch, New Paradigm, New Responsibilities." Eos 90: 49, 473-74.

Englehart, Neil A. 2000. "Rights and Culture in the Asian Values Argument: The Rise and Fall of Confucian Ethics in Singapore." Human Rights Quarterly 22(2): 54868.

Fairbanks, John King, and Merle Goldman. 2006. China. A New History. Cambridge, Mass and London: The Belknap Press of Harvard University Press.

Fan, Ruiping. 2010. Reconstructionist Confucianism. Rethinking Morality after the West. Dortrecht, Heidelberg, London, New York: Springer.

_- ed. 2011. The Renaissance of Confucianism in Contemporary China. Dordrecht: Springer.

Gänßbauer, Monika. 2011. Confucianism and Social Issues in China - The Academician Kang Xiaoguang. Investigations into NGOs in China, the Falun Gong, Chinese Reportage, and the Confucian Tradition. Bochum and Freiburg: Projekt Verlag. 
Gardner, Daniel K. 2011. "Mao Reclaims Tiananmen Square: For How Long?" Huffington Post, May 13, http://www.huffingtonpost.com/daniel-k-gardner/maoreclaims-tiananmen-sq_b_860710.html

Hansen, Valerie. 2000. The Open Empire. A History of China to 1600. New York and London: W.W. Norton \& Company.

Hong, Lysa, and Huang Jianli. 2008. The Scripting of a National History. Singapore and Its Pasts. Singapore: NUS Press.

Kuo, Eddie C.Y. 1996. "Confucianism as Political Discourse in Singapore: The Case of an Incomplete Revitalization Movement." In Confucian Traditions in East Asian Modernity: Moral Education and Economic Culture in Japan and the Four Mini-Dragons, edited by Tu Weiming, 294-309. Cambridge, Mass: Harvard University Press.

Levenson, James R. 1958-1965. Confucian China and Its Modern Fate: A Trilogy. Berkeley and Los Angeles: University of California Press.

Li Chi: Book of Rites. 1967. Vols. 1 \&2. Translated by James Legge. New York: University Books.

Mencius. 1970. Translated by D.C. Lau. Harmondsworth: Penguin.

Palsson, Gisli, et al. 2013. "Reconceptualizing the 'Anthropos' in the Anthropocene: Integrating the Social Sciences and Humanities in Global Environmental Change Research.” Environmental Science \& Policy, http://dx.doi.org/10.1016/j.envsci. 2012.11.004

Roberts, Dexter. 2012. "Confucius Makes a Comeback in China". Bloomberg Businessweek, Nov. 1, http://www.businessweek.com/articles/2012-1101/confucius-makes-a-comeback-in-china

Shobert, Benjamin A. 2011. "Confucius Reprises Role as Political Pawn.” Asia Times Online, Aug. 9, http://atimes.com/atimes/China/MH09Ad01.html

Sigurðsson, Geir. 2014. "Frugalists, Anti-Consumers and Prosumers: Chinese Philosophical Perspectives on Consumerism." In The Changing Landscape of China's Consumerism, edited by Alison Hulme. Cambridge: Chandos.

Song, Xianlin. 2003. "Reconstructing the Confucian Ideal in the 1980s China: The 'Cultural Craze' and New Confucianism." In New Confucianism. A Critical Examination, edited by John Makeham, 81-104. New York: Palgrave Macmillan.

Tu, Weiming. 1984. Confucian Ethics Today. The Singapore Challenge. Singapore: Curriculum Development Institute of Singapore.

—. 1993. "Confucian Traditions in East Asian Modernity: Exploring Moral Authority and Economic Power in Japan and the Four Mini-Dragons." Bulletin of the American Academy of Arts and Sciences 46(8): 5-19.

Weber, Max. 1930. The Protestant Ethic and the Spirit of Capitalism. Translated by Talcott Parsons. London: Harper Collins Academic. 
—. 1978. Die protestantische Ethik II. Kritiken und Antikritiken. Edited by Johannes Winckelmann. Gütersloh: Gütersloher Verlagshaus Gerd Mohn.

Yew, Leong. 2011. “A Brief History of the Hub: Navigating between 'Global' and 'Asian' in Singapore's Knowledge Economy Discourse.” In Singapore in Global History, edited by Derek Heng and Syed Muhd Khairudin Aljunied, 269-90. Amsterdam: Amsterdam University Press.

Zhao, Yong. 2007. “Why Are We Always Correcting Yu Dan's Mistakes?” Danwei, May 8, http://www.danwei.org/scholarship_and_education/yu_dan_defender_ of_traditional.php

Zhou, Liangfa 周良发. 2011. “Liang Qichao de rujia zhexue lun 梁启超的儒家哲学 论 (A Discussion of Liang Qichao's Confucian Philosophy).” Journal of Shanxi Datong University (Social Science) 山西大同大学学报（社会科学版）25(3): 27-30. 